\title{
OBTAINING LONG-TERM RESIDENT STATUS IN THE EUROPEAN UNION
}

\begin{abstract}
Mirna Romić*
Summary: This paper deals with obtaining long-term resident status in the European Union under Directive 2003/109/EC and problems arising from certain provisions. While enhancing the rights of legally resident third-country nationals, the Directive is in some aspects incompatible with the case law of the Court of Justice regarding citizens as well as international agreements regarding the free movement of persons. At the same time, the practical applicability of certain provisions is doubtful due to the wide margin of discretion given to Member States.
\end{abstract}

\section{Introduction}

This paper analyses the conditions that third-country nationals have to fulfil in order to obtain the long-term resident status regulated by Directive 2003/109/EC. I will analyse the conditions that the wording of the Directive sets applicants for this status, but will mostly deal with the interpretation of the conditions given by the Court of Justice of the European Union. Because there is a lack of Court case law in the interpretation of Directive 2003/109/EC, I will draw a parallel between this situation and ones that the Court has already dealt with in interpreting the conditions citizens are set for obtaining residency. Due to the complex nature of long-term residence status, I will also try to stress the consequences that the denial of this status can have on fundamental rights, such as the right to family life. I will then touch upon the acquisition of residence by family members of the long-term resident, stressing the difference between the notion of family and the right to family life. Taking into consideration the need for uniform application of Community law, I will try to point out the problems that could arise from the lack of Court case law in this area, especially concerning the administrative procedure for granting status. Finally, I will draw attention to the illogicality created by Directive 2003/109/EC, which is best seen when long-term residents are compared to the citizens of the new Member States who have not been put on an equal footing with other citizens due to transitional periods. The aim of this paper is the analysis of the conditions set before applicants for the status of long-term residents, their interpretation and the practical effects resulting from certain interpretative choices.

\footnotetext{
* Mirna Romić obtained her law degree from the Faculty of Law at the University of Zagreb in 2010 and is currently working as a junior associate at a law office in Zagreb.
} 


\section{Conditions for obtaining long-term resident status under Directi- ve $2003 / 109 / \mathrm{EC}$}

In this part of the paper, I will analyse the conditions set out by the wording of Directive 2003/109/EC. The first precondition for obtaining long-term resident status is a period of residency on the territory of a Member State. Secondly, there are the conditions set out by Directive 2003/109/EC. These can be divided into two categories: sufficient stable and regular resources and health insurance, on the one hand, and additional conditions that Member States can impose, on the other.

\subsection{Duration of residency on the territory of a Member State as a precondition for the obtainment of long-term residence status}

According to Article 4 of Directive 2003/109/EC, the main precondition for obtaining long-term resident status is legal residency on the territory of a Member State for a period of a minimum of five years prior to the application. ${ }^{1}$ The period of five years is probably chosen on the basis of national regulations for permanent residency, where the period prescribed varies from three to ten years. Given the fact that the aim of the Directive is the integration ${ }^{2}$ of legally resident third-country nationals and the approximation of their legal position to that of European citizens, the requirement of legal residency for a period of five years is an expected precondition. ${ }^{3}$ In order to avoid confusion regarding the categories of persons entitled to apply for such status, the Directive explicitly excludes certain categories from its scope in Article 3 (2). Persons who reside in a Member State in order to pursue studies and vocational training, seasonal workers and workers posted for the purpose of cross-border provision of services, and also cross-border providers of services with formally limited residence permits are excluded. Another group of persons excluded from the scope of the Directive is the category of refugees and persons under temporary or subsidiary protection. Lastly, the Directive does not apply to diplomats, consuls, members of specialised missions and representatives of international organisations.

Article 4 (2) regulates in detail periods of time which will not be taken into account when deciding on long-term residence status. Periods of time regulated by Article 3 (2e) and (2f) of Directive 2003/109/EC are not taken into consideration. These articles regulate periods of temporary

\footnotetext{
1 Council Directive 2003/109/EC of 25 November 2003 concerning the status of thirdcountry nationals who are long-term residents [2003] OJ L 16 art 4.

2 Council Directive 2003/109/EC (n 1) preamble (4); C-240 E/79 Proposal for Council Directive concerning the status of long-term residents who are third-country nationals [2001] OJ C 240E/2001 P 79 art 9 para 3.

3 Presidency Conclusions, A III Fair treatment of third country nationals 21, Tampere Council [1999] SN 200/99 COM/2007/0780, final Communication from the Commission, Towards a Common Immigration Policy [2007] SEC (2007) 1632.
} 
residence, residence of posted workers, residence related to the crossborder provision of services and situations in which a residence permit is formally limited. Likewise, periods of residency in a Member State during diplomatic or consular duty or duty in specialised missions are not taken into consideration. As far as residency during studies or vocational training is concerned, only half of the period is taken into consideration for the purpose of obtaining long-term resident status. ${ }^{4}$

In order for the precondition of duration of residence under the Directive to be considered fulfilled, the period of residency must not be interrupted by the long absence of the applicant from the territory of the Member State. Article 4 (3) regulates such situations by prescribing periods of absence which will not be considered as interrupting the period of residency. ${ }^{5} \mathrm{~A}$ period of absence must not be longer than six consecutive months and must not exceed ten months in total during a period of five years. However, the Directive allows Member States to adopt, in accordance with their national legislation, implementing measures which will take into consideration even longer periods of absence from their territory in exceptional circumstances. In addition, Member States are allowed to take into account periods of absence relating to secondment for employment purposes, including the provision of cross-border services.

Regarding the interpretation of the notion of duration of residence, it is imperative that such residency is legal. It is the established case law of the Court, eg in Gloszczuk and Panayotova, that the condition of legal residency, if it is clearly prescribed by legislation, has to be fulfilled before one tries to obtain the rights that the relevant legislation grants. ${ }^{6}$

Due to the fact that the aim of the Directive is the approximation of the legal position of legally resident third-country nationals with that of European citizens, Article 8 (3) of the Directive stresses the need to combat illegal immigration and the forgery of long-term residence permits. ${ }^{7}$

\subsection{Sufficient stable and regular resources of applicants for long- term resident status}

Although the duration of residency constitutes the principal condition $^{8}$ for obtaining long-term residence status, it cannot per se be con-

\footnotetext{
4 Council Directive 2003/109/EC (n 1) art 3 para 2 (a).

5 Council Directive 2003/109/EC, (n 1) art 4 para 3.

6 Case C-327/02 Lili Georgieva Panayotova and Others $v$ Minister voor Vreemdelingenzaken en Integratie [2004] ECR I-1 1055 paras 31 and 32; Case C-63/99 The Queen v Secretary of State for the Home Department, ex parte Wieslaw Gloszczuk and Elzbieta Gloszczuk [2001] ECR I-06369 para 77.

7 Council Directive 2003/109/EC (n 1) art 8 para 3.

8 Council Directive 2003/109/EC (n 1) preamble (6).
} 
sidered enough to obtain this status. ${ }^{9}$ A second condition that has to be fulfilled is the condition of stable and regular resources. More specifically, the Directive prescribes that such resources have to be stable and regular, and sufficient to maintain the applicant and his/her family members without recourse to the social assistance system of the Member State concerned. ${ }^{10}$ The first problem that arises from Article 5 (1a) is the meaning of the notion 'stable and regular resources'. The fact that every Member State has the right to check the availability of such resources, according to its own criteria prescribed by national legislation, leads to non-uniformity in the interpretation of Community law. The lack of interpretative practice of Directive 2003/109/EC can, in the worst case scenario, lead to the negation of rights given to individuals by the Directive, which is unacceptable from the aspect of Community law. ${ }^{11}$ Although one could argue that the notion could be explained by a reference to citizenship cases, it is still uncertain whether the Court would choose that interpretative path.

Taking into consideration the economic crisis that is taking place, one has to pay special attention to bank deposits as a category of stable and regular resources. Given the fact that sometimes the recovery of a deposit becomes practically impossible, eg due to non-implementation or faulty implementation of Directive 94/19/EC on deposit-guarantee schemes, the question of state responsibility for non-fulfilment of the prescribed condition of stable and regular resources arises. ${ }^{12}$ When considering the proper legal remedy for such hypothetical situations, it is necessary to try to redefine the rules on state responsibility and widen the application of the principle of estoppel. Besides the possibility of taking into consideration claims towards the state as stable and regular resources, one also has to consider the possibility of the financial support of a third person given to the applicant.

2.2.1. The principle of estoppel as a means of securing the fulfilment of the condition of stable and regular resources under Directive 2003/109/EC

The rationale of the principle of estoppel is not to allow a Member State to take advantage of its failure to fulfil its obligations under

\footnotetext{
9 Case C-413/99 Baumbast and $R v$ Secretary of State for the Home Department, [2002] ECR I-07091 paras 85, 87, 88 and 92; Case C-200/02 Kunqian Catherine Zhu and Man Lavette Chen $v$ Secretary of State for the Home Department [2004] ECR I-09925 para 47; Case C-456/02 Trojani v Centre public d'aide sociale de Bruxelles [2004] ECR I-07573 paras 32, 33 and 36.

10 Council Directive 2003/109/EC (n 1) art 5 para 1 (a).

11 Case C-5/88 Hubert Wachauf $v$ Bundesamt für Ernährung und Forstwirtschaft [1989] ECR 02609 para 18.

12 Council Directive 94/19/EC of the European Parliament and of the Council of 30 May 1994 on deposit-guarantee schemes [1994] OJ L135.
} 
Community law. ${ }^{13}$ Until now, estoppel has been applicable only in situations that include a single directive and the non-fulfilment of a state's obligations under that directive. However, due to the core meaning of the principle, it is my opinion that in a situation where invoking the provision of one directive would lead to a state taking advantage of its breach of Community law under another directive, the principle of estoppel has to be applicable. If one considers Article 5 (1a) of Directive 2003/109/EC, it is obvious that the reasoning behind the provision is the protection of the stability of social security systems in Member States. In a hypothetical situation in which the faulty implementation of a different directive, eg the above-mentioned Directive 94/19/EC, would lead to the denial of status by invoking Article 5 (1a) of Directive 2003/109/EC, such a denial would not be allowed. A different solution would lead to the paradoxical solution that Member States can take advantage of their failure to fulfil obligations under Community law in every situation that includes more than one directive. Such a solution would give Member States the opportunity to invoke their negligence in the implementation procedure in their own favour, thus jeopardising the efficiency of Community law.

It is my opinion that estoppel can also be used as a procedural instrument against the State. Regardless of the fact that, in my opinion, estoppel in its original sense is applicable to this situation, the problem of different directives that have to be legally connected in some way still remains. Some degree of connection has to exist between the directives in order to avoid the invoking of estoppel leading to the abuse of rights. The logical solution would be simply to apply the criterion developed in the Court's case law related to the principle of effective legal remedy. ${ }^{14}$ Therefore, in a situation where the faulty implementation of one directive, eg Directive 94/19/EC, makes the obtainment of rights under another directive, eg Directive 2003/109/EC, excessively difficult or virtually impossible, the state should do everything within its power to alleviate the burden of proof of stability of resources on the applicant. ${ }^{15}$ Specifically, if faulty implementation has made it impossible for the applicant to prove his/her stable and regular resources in order to obtain long-term resident status, the Member State concerned should consider the applicant's possible claims towards the state as stable and regular resources. The problem with this solution lies in the fact that Directive 2003/109/EC

13 Case C-148/78 Criminal proceedings against Tullio Ratti [1979] ECR 01629 para 22.

14 Case C-118/08 Transportes Urbanos y Servicios Generales SAL v Administración del Estado [2010] OJ C 63 para 31; Joined Cases C-317/08, C-318/08, C-319/08 and C-320/08 Rosalba Alassini $v$ Telecom Italia SpA, Filomena Califano $v$ Wind SpA, Lucia Anna Giorgia Iacono v Telecom Italia SpA and Multiservice Srl v Telecom Italia SpA, [2010] OJ C 134 para 47.

15 Case C-199/82 Amministrazione delle Finanze dello Stato v SpA San Giorgio [1983] ECR 03595, para 14 . 
and the case law of the Court do not define the notion 'stable and regular resources', which is why Member States enjoy a wide margin of discretion in this area. ${ }^{16}$

Claims towards the state based on the direct effect of a certain provision in a directive should, in the above situation, be taken into consideration when deciding on the fulfilment of the requirement of stable and regular resources. If we consider the provision of Directive 94/19/EC, the requirement would not be fulfilled since the provision of Article 7 does not have direct effect. However, the amendment to Directive 94/19/EC nominates the state as the party responsible for the reimbursement of depositors, which is why the amended provision fulfils the conditions for direct effect. ${ }^{17}$ The consequence is that the reimbursement of deposits under Directive 94/19/EC could not be based on the direct effect of Article 7, since this article stipulates that it is the deposit guarantee schemes, not states, which are responsible for reimbursement. This situation is similar to, if not the same as, the one that occurred in Francovich, ${ }^{18}$ which is why an action for damages against the state has to be considered.

Action for damages against the state could be considered in a situation where a Member State has breached Community law. For that to be possible, the criteria established by the Court in Francovich and Brasserie du Pêcheur ${ }^{19}$ have to be fulfilled. If one takes into consideration the above-mentioned Directive 94/19/EC, the first condition set by the Court, which is that the provision breached must grant rights to individuals, would definitely be fulfilled, since the provision clearly and precisely stipulates that each individual shall be reimbursed up to EUR 20,000. The other conditions, namely the sufficiently serious breach of Community law and a causal link between the breach and damages to the individual, would have to be assessed according to the specific circumstances of each particular case.

\subsubsection{Support as a means of securing stable and regular resources}

One of the possible means of securing the fulfilment of the condition of having stable and regular resources is support provided by a third

16 Case C-578/08 Rhimou Chakroun v Minister van Buitenlandse Zaken [2010] OJ C 113 para 51.

17 Directive 2009/14/EC of the European Parliament and of the Council of 11 March 2009 amending Directive 94/19/EC on deposit-guarantee schemes as regards the coverage level and the payout delay [2009] OJ L 68 art 1 para 3.

18 Joined Cases C-6/90 and C-9/90 Andrea Francovich and Danila Bonifaci and others $v$ Italian Republic [1991] ECR I-05357 para 26.

19 Joined Cases C-46/93 and C-48/93 Brasserie du Pêcheur SA v Bundesrepublik Deutschland and The Queen $v$ Secretary of State for Transport, ex parte: Factortame Ltd and others, [1996] ECR I-01029 paras 56 and 74. 
person. ${ }^{20}$ The aim of Directive 2003/109/EC, as confirmed by the Commission, is the integration of third-country nationals, which is why financial support provided by a third person should also be taken into consideration. ${ }^{21}$ If the stability of resources is certain, their origin is irrelevant, as confirmed by the Court. ${ }^{22}$ The most recent case law indicates that the requirement of having stable and regular resources is not absolute but depends on the circumstances of each case, as confirmed in Ibrahim..$^{23}$ The practical reason why the Court takes into consideration support provided by a third person, regardless of the nature of their relationship, is the fact that the nature of a relationship is irrelevant when considering the uncertainty of future circumstances. The irrelevance of a legal link between the provider and the recipient of support can easily be illustrated by the example of a spouse unable to seek support after a marriage has ended. A different interpretation would leave too much discretion to Member States about the categories of persons encompassed by the notion 'provider of the support' and probably reduce it to spouses and close relatives. In Commission $v$ Belgium, the Court stated that loss of support is always an underlying risk, even in a situation when the other person undertakes to support the recipient of the support. Therefore, the requirement of a legal link between the provider and the recipient of the support is a disproportionate measure that hinders the fundamental freedom of movement of persons. ${ }^{24}$

\subsubsection{Determining the sufficiency of resources}

According to the precise wording of Article 5 (1a) of the Directive, resources have to be sufficient for the applicant to be able to support himseIf/herself and his/her family members without recourse to the Member State's social security system. ${ }^{25}$ However, since the article does not mention any exact amount of money or an indication of how to calculate it, the term is left for national legislation to regulate. It can be read from the preamble to the Directive, which can be used as a guide for interpretation, that the reasoning behind this provision is protection of Member States' social security systems, namely to avoid the long-term resident becoming a burden on the Member State's social security system. ${ }^{26}$ One should bear

\footnotetext{
20 D Martin and E Guild, Free Movement of Persons in the European Union (Butterworths, London 1996).

${ }^{21}$ Commission (EC), 'Towards a Common Immigration Policy' (Communication to the European Parliament, the Council, the European Economic and Social Committee and the Committee of Regions) COM (07) 780 final [2007] SEC (2007) 163.

${ }^{22} Z$ Zhu and Chen (n 9) para 30; Case C-408/03 Commission of the European Communities $v$ Belgium [2006] ECR I-02647 para 42.

23 Case C-310/08 London Borough of Harrow v Nimco Hasan Ibrahim, Secretary of State for the Home Department [2010] OJ C 100 para 59.

24 Commission v Belgium (n 22) paras 41 and 47.

25 Council Directive 2003/109/EC (n 1) art 5 para 1 (a).

26 Case C-418/04 Commission of the European Communities $v$ Ireland [2007] ECR I-10947 paras 84, 120, 172; Case C-278/05 Carol Marilyn Robins and Others $v$ Secretary of State for Work and Pensions [2007] ECR I-01053 para 38.
} 
in mind that the Court stated in Baumbast that the right of residence can be subordinated to the legitimate interests of Member States. ${ }^{27}$ In addition, the situation in Baumbast differs from that under Directive 2003/109/ EC because long-term residents must not become a burden (the adjective 'unreasonable' is not added in this case) to the Member State concerned. ${ }^{28}$ However, the proportionality test should be applied in each particular case so that the discretion provided is not misused.

The problem of sufficiency of resources appeared before the Court in Chakroun. ${ }^{29}$ Questions were posed as to whether or not a Member State can define the minimum amount necessary to fulfil the condition of having stable and regular resources as well as the concept of social assistance. Although the Court admitted the right of every Member State to indicate a certain amount, it stressed that it cannot be framed as a fixed amount under which all applications will be rejected. ${ }^{30}$ It also emphasised that the notion 'recourse to the social security system' means that such assistance has to compensate for the lack of stable and regular resources and is not only a temporary aid in exceptional circumstances. ${ }^{31}$ Such an interpretation of the Court lessened the discretion of Member States in the implementation procedure, consequently diminishing the possibility of non-uniformity in the application of Community law.

\subsection{Health insurance of applicants for long-term resident status}

Having health insurance is a condition for obtaining long-term resident status prescribed in Article 5 (1b) of Directive 2003/109/EC. ${ }^{32}$ This condition is expected, since it is also imposed on European citizens who apply for residence longer than three months. ${ }^{33}$

\subsection{Additional integration conditions prescribed by the national legislation of Member States}

Article 5 (2) of the Directive allows Member States to set third-country nationals who apply for long-term resident status additional integration conditions. ${ }^{34}$ This provision encompasses measures that facilitate the integration of third-country nationals such as language proficiency

\footnotetext{
27 Case C-413/99 Baumbast and R v Secretary of State for the Home Department [2002] ECR I-07091 para 90.

28 Directive 2003/109/EC (n 1) preamble (7).

29 Chakroun (n 16).

30 Chakroun (n 16) para 48.

31 Chakroun (n 16) para 49.

32 Council Directive 2003/109/EC (n 1) art 5 para 1 (b).

33 Council Directive 2004/38/EC of the European Parliament and of the Council on the right of citizens of the Union and their family members to move and reside freely within the territory of the Member States OJ L 229/35 art 7 para 1 (b).

34 Directive 2003/109/EC (n 1) art 5 para 2.
} 
or acquaintance with the culture or customs of the Member State concerned. ${ }^{35}$ However, setting these additional conditions cannot go as far as to negate the very aim of the Directive by making the obtainment of longterm resident status excessively difficult or virtually impossible. ${ }^{36}$

\section{The right of family members of long-term residents to reside on the territory of Member States}

Analysis of the rights of family members of long-term residents is maybe not the most controversial issue under this Directive, but it is extremely important due to recent developments in Community law related to general principles. Long-term residents' family members, if the family was previously constituted in another Member State, have the right to accompany or to join the long-term resident. ${ }^{37}$ This does not mean that they acquire long-term resident status, but only the right to accompany or to join the long-term resident.

\subsection{Conditions for residence of family members of long-term resi- dents under Directive 2003/109/EC}

The first condition that family members have to fulfil is that they are covered by Article 4 (1) of Directive 2003/86/EC on the right to family reunification. This article regulates the categories of persons encompassed by the notion 'family member' for the purpose of family reunification. Family members entitled to family reunification under this article can be put into two categories: the sponsor's spouse and minor dependent children, whether biological or adopted. ${ }^{38}$

Regarding other possible family members, Directive 2003/109/EC stipulates that such persons may be granted the right of residence with the long-term resident. ${ }^{39}$ The second condition that family members have to fulfil is that they present their residence permit from the Member State in which they previously resided as well as evidence that family union existed before they moved to the host Member State. They also have to prove that they have sufficient stable and regular resources without recourse to social assistance and health insurance or that the long-term resident whom they are joining has such resources and insurance for

\footnotetext{
35 S Carrera, 'Integration as a Process of Inclusion of Migrants? The Case of Long-term Residents in the EU' [2005] CEPS working documents no 219, 9; C Barnard, The Substantive Law of the EU: The Four Freedoms (OUP, Oxford 2007) 515.

${ }_{36}$ Case C-5/88 Hubert Wachauf $v$ Bundesamt für Ernährung und Forstwirtschaf, [1989] ECR 02609 para 18.

37 Council Directive 2003/109/EC (n 1) art 16 para 1.

38 Council Directive 2003/86/EC of 22 September 2003 on the right to family reunification OJ 2003 L 251 art 4 para 1.

39 Directive 2003/109/EC (n 1) art 16 para 2.
} 
them. ${ }^{40}$ Directive 2003/109/EC shall not be applicable if the family union was not formed before moving to the host Member State. In this situation, Directive 2003/86/EC shall apply. ${ }^{41}$

\subsection{Family and the right to family life}

Because of the exclusive competence of the Member States in the field of family law, the possibility arises for Member States to decrease the number of persons who are regarded as family members in certain national legislations (but who are not explicitly listed in the text of the Directive as family members entitled to rights under the Directive, eg same-sex partners), thus limiting their ability to obtain rights under Directive 2003/109/EC. ${ }^{42}$ Although the wording of the Directive allows such national legislation to be enforced, it is questionable whether or not such practice is compatible with the case law of the European Court of Human Rights. This problem is even more complex if we take into consideration the enforcement of the Lisbon Treaty, which stipulates in Article 6 that the European Union shall accede to the European Convention for the Protection of Human Rights and Fundamental Freedoms. ${ }^{43}$ If that happens, the European Union is going to be bound by the case law of the Strasbourg court. In addition to this, the above-mentioned article of the Treaty gives the Charter of Fundamental Rights of the European Union legal power equivalent to that of the Treaties, which is why Article 7 of the Charter brings the right to family life within the scope of Community law. A problem arises because the case law of the Strasbourg court grants the right to family life to a broader circle of persons than those who are considered to be family members in Member States. This issue will often arise in cases involving cohabitants, especially same-sex partners.

\subsubsection{The role of the right to family life in Community law before possible accession to the Convention for the Protection of Human Rights and Fun- damental Freedoms}

The right to family life is primarily a common constitutional value of Member States, which can be seen from their constitutional traditions as well as the fact that all Member States are parties to the Convention. ${ }^{44}$ It is the established case law of the Court to consider common con-

\footnotetext{
40 Directive 2003/109/EC (n 1) art 16 para 4.

41 Directive 2003/109/EC (n 1) art 16 para 5.

42 Consolidated version of the Treaty on European Union art 1; consolidated version of the Treaty on the Functioning of the European Union [2002] OJ 2002 C 325 title I art 2.

43 Treaty on European Union (n 42) art 6 para 2.

44 Basic Law for the Federal Republic of Germany of 8 May 1949 (Grundgesetz für die Bundesrepublik Deutschland) 2009 BGBl.I S.2248, art 6 para 1; Constitution of the Czech Republic of 16 December 1992 (Ústava České republiky) 1992 č 1/1993 Sb, art 112; Charter of fundamental rights and freedoms (Listina základních práv a svobod) 1992 č 2/1993 Sb, article 10 para 2; Constitution of Ireland of 29 December 1937 (Bunreacht na hÉireann),
} 
stitutional values and international agreements to which Member States are parties or have participated in the making of as an interpretative guide in the application of Community law. ${ }^{45}$ The European Convention for the Protection of Human Rights and Fundamental Freedoms has special significance in this regard. The Court often stresses this importance by invoking the Convention as well as the case law of the Strasbourg court in cases involving fundamental rights. ${ }^{46}$ Even so, the Court has never in its practice given the right to family life the status of a right which individuals can invoke, but rather considered it as a guide in interpretation.

\subsubsection{The right to family life as a general principle of Community law}

Given the fact that fundamental rights form a part of the general principles of Community law, the observance of which the Court ensures, and the fact that the Charter now has the same legal power as the Treaties, it is expected that the practice of the Court regarding Article 7 of the Charter will change. ${ }^{47}$ Even if the Charter had not been given such legal power one should consider the standpoint of the Court in Mangold and Kücükdeveci where the Court gave direct effect to general principles even in horizontal situations. ${ }^{48}$ Again, the problem occurs with the interpretation of the notion of 'family life'. The Court could handle this in two ways, either to await the accession of the Union to the Convention and a legislative solution to the relationship between the two courts or to give its own, autonomous, interpretation of family life. In the latter case, it should, however, bear in mind that Article 7 of the Charter was modelled on Article 8 of the Convention, which is why the job of creating a whole new interpretative practice around the same term would not be necessary. ${ }^{49}$

1998 Official Gazette, Acts, 15 p, art 41; Spanish Constitution of 29 December 1978 (Constitución Española) 1978 BOE 311, art 39 para 1; The Constitution of the Republic of Poland of 17 October 1997 (Konstytucja Rzeczypospolitej Polskiej) 1997 Dziennik Ustaw nr 78 poz 483 art 47; The Constitution of the Italian Republic of 27 December 1947 (Costituzione della Repubblica Italiana) 1947 Gazzetta Ufficiale n 298 art 31; Human Rights Act 1998, c 42, Convention rights, <http://www.statutelaw.gov.uk>, accessed 27 November 2010 art 1 paras 1 and 2; Convention for the Protection of Human Rights and Fundamental Freedoms as amended by Protocol No 11, Rome 4 November 1950, 2010 CETS no 194 art 8.

45 Case 4-73 J Nold, Kohlen- und Baustoffgroßhandlung $v$ Commission of the European Communities [1974] ECR 00491 para 13.

46 Case 36/75 Roland Rutili v Ministre de l'intérieur [1975] ECR 01219 para 32; Case C-60/00 Mary Carpenter $v$ Secretary of State for the Home Department [2002] ECR I-06279 paras 41 and 42; Case C-109/01 Secretary of State for the Home Department $v$ Hacene Akrich [2003] ECR I-09607 para 3; Case C-540/03 European Parliament $v$ Council of the European Union [2006] ECR I-05769 paras 4 and 35; Case C-127/08 Blaise Baheten Metock and Others $v$ Minister for Justice, Equality and Law Reform [2008] ECR I-06241 para 79; Joined Cases 482/01 and 493/01 Georgios Orfanopoulos and Others and Raffaele Oliveri $v$ Land Baden-Württemberg [2004] ECR I-05257 paras 14, 98 and 99.

47 European Parliament $v$ Council of the European Union (n 46) para 35.

48 Case C-144/04 Werner Mangold v Rüdiger Helm [2005] ECR I-09981 para 77; Case C-555/07 Seda Kücükdeveci v Swedex GmbH\&Co.KG [2010] OJ C 63 paras 50, 51 and 54.

49 EU Network of Independent Experts on Fundamental Rights, 'Commentary of the Charter of Fundamental Rights of the European Union' (June 2006) <http://www. ec.europa. eu> accessed 27 November 2010 pp 78 and 85. 
3.2.3. Differences in the interpretation of the term 'family life' in the case law of the Court of Justice of the European Union and the European Court of Human Rights

The Court avoided giving an extensive interpretation of the term 'spouse' by limiting its scope to married couples only, eg Reed. ${ }^{50}$ This brought into question the possibility of other life partners invoking their right to family life. ${ }^{51}$ However, in certain cases, like Eyüp, the Court took into consideration periods of cohabitation when deciding on individual rights. ${ }^{52}$ On the other hand, the approach of the European Court of Human Rights is quite different. Basing its reasoning on the reality of the relationship rather than its form, this court also acknowledged the right to family life in situations that did not involve married couples. ${ }^{53}$ If the European Union decides to accede to the Convention, this will create a problem in the application of Community law because the Court will have to take into consideration the interpretation of the Strasbourg court. The consequence will be that the division of competences in the European Union will be disturbed, since Member States will be obliged to bring their national conceptions of the term 'family' into conformity with the conception of the Strasbourg court. Widening the scope of the term 'family' to persons who have not been included in it so far will lead to the need to amend Article 16 of Directive 2003/109/EC as well as Article 4 of Directive 2003/86/EC so as to recognise the right to family reunification for those new categories of family members, eg cohabitants.

\section{Problems in the application of Directive $2003 / 109 /$ EC}

Directive 2003/109/EC provoked a lot of positive as well as negative reactions from legal experts. ${ }^{54}$

The most striking problem would probably be that of Article 11, which gives long-term residents the right to equal treatment in relation

\footnotetext{
50 Case C-59/85 The State of Netherlands $v$ Ann Florence Reed [1986] ECR 01283 para 15.

51 Reed (n 50) para 15; Case C-249/96 Lisa Jacqueline Grant $v$ South-West Trains Ltd [1998] ECR I-00621 para 45.

52 Case C-65/98 Safet Eyüp v Landesgeschäftsstelle des Arbeitsmarktservice Vorarlberg [2000] ECR I-04747 para 36.

53 C McGlynn, Families and the European Union (CUP, Cambridge 2006) 134; Johnston and Others $v$ Ireland, judgement of 18 December 1986 (1986) Series A no 122 para 56; Kroon and others $v$ The Netherlands, judgement of 27 October 1994 (1994) Series A no 297 para 30.

54 DA Arcarazo, 'Directive 2003/109 or the Legal Exclusion of the Long-term Resident "Other"' in C Murphy and P Green, Law and Outsiders: Norms, Processes and 'Othering' (Hart Publishing 2010, Oxford); S Peers, 'Implementing Equality? The Directive on Longterm Resident Third Country Nationals' (2004) 29 ELR 437-460; K Groenendijk, 'Legal Concepts of Integration in EU Migration Law' (2004) 6 European Journal of Migration and Law 111-126.
} 
to citizens in numerous areas, eg access to employment. ${ }^{55}$ This, however, puts the citizens of the new Member States in a worse position than long-term residents. Due to the transitional periods that will be activated after accession, workers from new Member States will be put in a worse position than workers who are long-term residents, which is directly contrary to the Court's position in Sahin, where it stressed that European citizens cannot be put in a worse position than third-country nationals. ${ }^{56}$ Specifically, the principle of Union preference comes into question. The Directive gives long-term residents the right to equal treatment in relation to Union citizens in the area of access to employment. This may be interpreted in a way that long-term residents in France, for example, have the same right of access to employment as Irish or German citizens in France, but not Romanian citizens in France, because a transitional period applies to Romanian workers. In this specific situation, either the principle of Union preference has to be redefined or the text of Directive $2003 / 109 / \mathrm{EC}$ has to be amended in a way that indicates which of the two categories of Union citizens long-term residents are equal with regarding the right of access to employment.

Another problem arises in the area of the Union's international agreements that regulate the free movement of persons, eg the agreement with Switzerland. ${ }^{57}$ Firstly, this was signed before long-term residency even existed. Secondly, the Agreement and the Directive regulate basically the same legal area in a fairly similar way. The only practical difference is that the Directive puts a long-term resident in a position which is similar to that of a Union citizen. ${ }^{58}$ Considering the administrative charges for long-term residence permits in Member States, it is easy to conclude that citizens of those countries who have signed free movement of persons treaties with the European Union would hardly decide to apply for long-term resident status. ${ }^{59} \mathrm{~A}$ possible solution to the problems that may appear if such third-country nationals decide to apply for long-term resident status could be the supremacy of international agreements over acts of secondary legislation. ${ }^{60}$ This, however, still does not settle the conflict of

55 Directive 2003/109/EC (n 1) art 11.

56 Case C-242/06 Minister voor Vreemdelingenzaken en Integratie $v$ T Sahin [2009] OJ C 267 para 69.

57 Agreement between the European Community and its Member States, of the one part, and the Swiss Confederation, on the other, on the free movement of persons [1999] OJ L 114.

58 Directive 2003/109/EC (n 1) preamble (2).

59 The fee for a long-term residence permit in Sweden is SEK 1,000; in Poland PLN 650; in Greece EUR 900.

60 Case C-308/06 International Association of Independent Tanker Owners (Intertanko) and Others $v$ Secretary of State for Transport [2008] ECR I-04057 para 42; Joined Cases 402/05 and 415/05 Yassin Abdullah Kadi and Al Barakaat International Foundation $v$ Council of the European Communities [2008] ECR I-06351 para 307. 
implementation measures unless one would, analogously, give priority to the implementation measure of an international agreement.

The third problem is the possibility of impeding the achievement of the aim of the Directive by posing additional integration conditions in national law. Although the rationale of Article 5 (2) was not to encourage national legislators to impose additional conditions, it is easy to imagine numerous ways of misusing the provision. During the preparatory procedure, Germany and Austria insisted that the term 'integration measures' be replaced with 'integration conditions', which led to the spill-over of costs, eg for language courses, from Member States to applicants for long-term resident status. ${ }^{61}$

Although every criticism of Directive 2003/109/EC is justified, the Directive is still a positive step in the integration of third-country nationals because it allows them, according to the level of their integration into the society, to enhance their rights and approximate their legal position to that of Union citizens. ${ }^{62}$

\section{Conclusion}

Directive 2003/109/EC, as an instrument that regulates long-term residence status for the first time at the level of the European Union, is a positive step in resolving numerous problems related to immigration. The peculiarity of this Directive is that it gives a special status to legal residents who have resided on the territory of Member States longer than five years, which differentiates them not only from illegal immigrants but also from persons who have resided in the Union for a shorter period. Because of this, the scope of rights of long-term residents is significantly wider than that of persons with temporary residence or even persons who obtain resident permits under the national legislations of Member States. This is because the Directive brings long-term residents within the scope of Community law, thus allowing them to move freely between Member States. In addition, the fact that they are within the scope of Community law allows them to invoke its general principles and rely on the Court's interpretation of certain legal terms. Regardless of the fact that the very wording of Directive 2003/109/EC gives long-term residents the right to equal treatment in relation to European citizens in numerous areas, the efficiency of these provisions will have to be tested in practice. Here, the interpretation of the Court will be indispensable.

\footnotetext{
${ }^{61}$ K Groenendijk (n 54).

62 Tampere European Council, Presidency Conclusions 15 and 16 October 1999, Bulletin of the European Union No 10/1999 paras 18 and 21.
} 